\title{
Gambaran eritrosit urin pada pasien tuberkulosis paru dewasa di RSUP Prof. Dr. R. D. Kandou Manado
}

\author{
${ }^{1}$ Gracia S. Sinaga \\ ${ }^{2}$ Glady I. Rambert \\ ${ }^{2}$ Mayer F. Wowor
}

\author{
${ }^{1}$ Kandidat Skripsi Fakultas Kedokteran Universitas Sam Ratulangi Manado \\ ${ }^{2}$ Bagian Patologi Klinik Fakultas Kedokteran Universitas Sam Ratulangi Manado \\ Email: ellasinaga13@gmail.com
}

\begin{abstract}
Tuberculosis is an infectious disease caused by Mycobacterium tuberculosis. Tuberculosis remains a major global health problem and ranks as the second leading cause of death from an infectious disease worldwide. Anti-tuberculosis drugs, such as streptomycin and rifampicin are nephrotoxic. If the kidney function decreased, especially the glomerulus there can be found blood cells in the urine. A small number of erythrocytes may be found in normal urine, about 0-2 cells per HPF (High Power Field). But more than three erythrocytes per HPF is generally considered hematuria. This study aims to describe about how the urine erythrocytes in adult pulmonary tuberculosis patients at RSUP Prof. Dr. R. D. Kandou Manado. Research design used is descriptive observational research. Samples were urine samples of all pulmonary tuberculosis patients that suit to inclusion criteria. This study was conducted from October to November 2016. The results of chemical urinalysis of urine erythrocytes are negative in 20 patients and positive in 10 patients, while the results of microscopic urinalysis of urine erythrocytes are normal in 26 patients and hematuria in 4 patients. Conclusion: Hematuria mostly found in males, age 56-65 years old, default tuberculosis type, the first category of anti-tuberculosis drugs, the duration of therapy about 3-4 months, and in patients with comorbid disease.
\end{abstract}

Keywords: pulmonary tuberculosis, urinalysis, hematuria

\begin{abstract}
Abstrak: Tuberkulosis merupakan penyakit infeksi yang disebabkan oleh Mycobacterium tuberculosis. Tuberkulosis masih merupakan salah satu masalah kesehatan masyarakat di dunia dan menduduki peringkat kedua penyebab kematian oleh penyakit infeksi di dunia. Obat anti-tuberkulosis seperti streptomisin dan rifampisin memiliki efek nefrotoksik. Apabila fungsi ginjal terutama glomerulus telah rusak maka dapat ditemukan adanya eritrosit dalam urin. Pada urin normal terdapat eritrosit sekitar 0-2 sel/LPB. Jika ditemukan 3 sel/LPB atau lebih, maka disebut hematuria. Penelitian ini bertujuan untuk mengetahui gambaran eritrosit urin pada pasien tuberkulosis paru dewasa di RSUP Prof. Dr. R.D. Kandou Manado. Desain penelitian yang digunakan adalah deskriptif observasional. Sampel penelitian adalah sampel urin sewaktu dari semua pasien tuberkulosis paru yang memenuhi kriteria inklusi. Penelitian dilakukan sejak Oktober-November 2016. Dari hasil pemeriksaan eritrosit urin secara kimia didapatkan hasil negatif pada 20 pasien dan hasil positif pada 10 pasien, sedangkan pemeriksaan mikroskopis eritrosit urin ditemukan hasil normal pada 26 pasien dan hasil hematuria pada 4 pasien. Simpulan: Hematuria didapatkan lebih banyak pada pasien laki-laki, pada kelompok usia 56-65 tahun, pada jenis kasus putus obat, pada jenis pengobatan kategori 1, pada lama pengobatan 3-4 bulan, dan pada pasien dengan penyakit penyerta.
\end{abstract}

Kata kunci: tuberkulosis paru, urinalisis, hematuria

Tuberkulosis (TB) merupakan penyakit infeksi yang disebabkan oleh 
Mycobacterium tuberculosis. Sampai saat ini TB masih merupakan salah satu masalah kesehatan masyarakat di dunia dan menduduki peringkat kedua penyebab kematian oleh penyakit infeksi di dunia setelah HIV, walaupun sejak tahun 1995 upaya pengendalian dengan strategi DOTS telah diterapkan di banyak negara. ${ }^{1}$

Tahun 2015 terdapat 10,4 juta kasus baru tuberkulosis di dunia, dimana terdapat 5,9 juta $(56 \%)$ kasus pada laki-laki, 3,5 juta (34\%) kasus pada perempuan, dan 1 juta $(10 \%)$ kasus pada anak-anak Beberapa negara yang mencapai $60 \%$ kasus baru antara lain India, Indonesia, China, Nigeria, Pakistan, dan Afrika Selatan. ${ }^{2}$

Prevalensi penduduk Indonesia yang didiagnosis tuberkulosis paru oleh tenaga kesehatan tahun 2013 adalah 0,4 \%, sama dengan pada tahun 2007. Di Sulawesi Utara, prevalensi penduduk tuberkulosis paru adalah $0,3 \%$ dari jumlah penduduk dan di kota Manado pada tahun 2013 diperkirakan 1198 orang terdiagnosis menderita tuberkulosis. ${ }^{3}$

Tuberkulosis merupakan penyakit kronik dengan jangka waktu pengobatan yang cukup lama, minimal 6 bulan agar dapat mencegah perkembangan resistensi obat. Pengobatan tuberkulosis adalah salah satu strategi utama pengendalian tuberkulosis karena dapat memutuskan rantai penularan. Pengobatan yang diberikan kepada pasien tuberkulosis paru dibagi menjadi dua tahap, yaitu tahap awal atau intensif dan tahap lanjutan. World Health Organization merekomendasikan obat kombinasi dosis tetap (KDT) untuk mengurangi risiko resistensi obat akibat monoterapi. ${ }^{4}$

Obat anti-tuberkulosis seperti streptomisin dan rifampisin memiliki efek nefrotoksik akibat akumulasi obat di ginjal serta melalui reaksi hipersensitifitas tipe II dan III, namun mekanisme ini belum diketahui secara pasti. ${ }^{5,6}$ Kerusakan ginjal terutama pada glomerulus dapat menimbulkan gejala hematuria atau adanya sel darah merah pada urin. ${ }^{7}$

Urin merupakan zat sisa metabolisme yang dibentuk oleh ginjal melalui tiga proses, yaitu filtrasi glomerulus, reabsorpsi tubulus, dan sekresi tubulus. ${ }^{8}$ Urin telah digunakan sebagai alat diagnostik yang utama sejak zaman dahulu, namun sekarang ini urin digunakan untuk mendiagnosis kondisi tertentu. ${ }^{9}$

Pemeriksaan urin atau urinalisis terdiri dari tiga jenis pemeriksaan, yaitu pemeriksaan makroskopik, mikroskopik, dan kimia urin. Untuk menilai eritrosit dalam urin digunakan pemeriksaan kimia urin dengan metode carik celup (dipstick) dan melalui pemeriksaan sedimen menggunakan mikroskop. ${ }^{10}$ Pada urin normal sebenarnya terdapat eritrosit namun dalam jumlah kecil, apabila sudah ditemukan $\geq 3$ eritrosit/LPB maka disebut sebagai hematuria. ${ }^{11}$

Penelitian ini bertujuan untuk mengetahui gambaran eritrosit urin pada pasien tuberkulosis paru dewasa di RSUP Prof. Dr. R.D. Kandou Manado.

\section{METODE PENELITIAN}

Jenis penelitian ini ialah deskriptif observasional. Penelitian dilaksanakan di RSUP Prof. Dr. R. D. Kandou Manado selama bulan Oktober sampai November 2016. Sampel penelitian ialah sampel urin sewaktu dari semua pasien tuberkulosis paru yang memenuhi kriteria inklusi yang telah ditentukan dengan cara nonprobability sampling jenis consecutive sampling.

\section{HASIL PENELITIAN DAN BAHASAN}

Berdasarkan penelitian yang telah dilakukan dengan cara mengambil sampel urin pasien tuberkulosis paru dewasa di Poliklinik Paru dan rawat inap bagian Ilmu Penyakit Dalam RSUP Prof. Dr. R. D. Kandou Manado diperoleh sebanyak 30 pasien yang terdiri dari 6 pasien rawat inap dan 24 pasien rawat jalan kemudian dilakukan pemeriksaan sampel urin di Laboratorium Pro-Kita Manado.

Pada penelitian didapatkan kelompok usia 36-45 tahun merupakan kelompok usia terbanyak yang menderita tuberkulosis paru yaitu sebanyak 8 orang $(26,7 \%)$ dari total 30 pasien. Hasil penelitian ini tidak jauh 
berbeda dengan data dari penelitian Mori Toru $^{12}$ yang menunjukkan bahwa tuberkulosis paru relatif terjadi pada kelompok usia 35-44 tahun. Sedangkan dari hasil penelitian yang dilakukan oleh Zhang dkk $^{13}$ didapatkan bahwa sebanyak $44,8 \%$ kasus tuberkulosis terjadi pada kelompok umur 25-44 tahun.

Tabel 1. Distribusi pasien TB paru menurut usia

\begin{tabular}{ccc}
\hline Usia & Jumlah & $\boldsymbol{\%}$ \\
\hline 18-25 Tahun & 4 & $13,3 \%$ \\
26-35 Tahun & 4 & $13,3 \%$ \\
36-45 Tahun & 8 & $26,7 \%$ \\
46-55 Tahun & 6 & $20,0 \%$ \\
56-65 Tahun & 6 & $20,0 \%$ \\
66-75 Tahun & 2 & $6,7 \%$ \\
Total & 30 & $100,0 \%$ \\
\hline
\end{tabular}

Pada penelitian secara keseluruhan terdapat 20 orang laki-laki $(66,7 \%)$ dan 10 orang perempuan $(33,3 \%)$. Hasil ini sesuai dengan data dari $\mathrm{WHO}^{2}$ yang menunjukkan bahwa pasien laki-laki (56\%) lebih banyak dari perempuan (34\%). Hasil yang sama juga ditemukan pada penelitian yang dilakukan di RSUD Arifin Rachmad Pekanbaru, yang menyebutkan bahwa lakilaki $(59,4 \%)$ lebih rentan terkena tuberkulosis paru dibandingkan perempuan $(40,6 \%)$. Hal ini kemungkinan berkaitan dengan kebiasaan merokok yang mengakibatkan sistem imun menurun serta laki-laki juga memiliki kebiasaan seharihari yang lebih banyak berada di luar rumah sehingga risiko terpapar dengan Mycobacterium tuberculosis dari penderita tuberkulosis paru lain menjadi lebih besar. $^{14}$

Tabel 2. Distribusi pasien TB paru menurut jenis kelamin

\begin{tabular}{ccc}
\hline Jenis Kelamin & Jumlah & \% \\
\hline Laki-laki & 20 & $66,7 \%$ \\
Perempuan & 10 & $33,3 \%$ \\
Total & 30 & $100 \%$ \\
\hline
\end{tabular}

Pada penelitian didapatkan gangguan ginjal menjadi penyakit komorbid terbanyak yaitu menyerang 6 dari total 30 pasien yang menjadi sampel (20,0\%). Gangguan ginjal seperti gagal ginjal kronik juga menjadi penyakit penyerta dari tuberkulosis karena penyakit tersebut memengaruhi penurunan mekanisme sistem imun. Penyakit ginjal kronik dapat menyebabkan uremia yang memengaruhi penurunan beberapa keadaan diantaranya respon sel $\mathrm{T}$ terhadap mitogen, hipersensitifitas yang melambat, serta aktivitas fagositosis dari sel mononuklear. Perubahan morfologi yang terjadi pada parekim paru akibat toksisitas uremia dapat mempengaruhi bersihan mukosilier (mucocilliary clearance) dan kemampuan pertahanan endotel dan epitel. ${ }^{15}$

Tabel 3. Distribusi pasien TB paru menurut penyakit penyerta

\begin{tabular}{ccc}
\hline Penyakit Penyerta & Jumlah & \% \\
\hline Hipertensi & 4 & $13,3 \%$ \\
Asam urat & 5 & $16,7 \%$ \\
Diabetes melitus & 5 & $16,7 \%$ \\
Gangguan ginjal & 6 & $20,0 \%$ \\
\hline
\end{tabular}

Pada penelitian didapatkan pasien tuberkulosis paru kasus baru sebanyak 13 orang $(43,3 \%)$, kasus putus obat sebanyak 8 orang $(26,7 \%)$, kasus gagal terapi sebanyak 1 orang $(3,3 \%)$, dan kasus relaps sebanyak 8 orang $(26,7 \%)$. Penelitian sebelumnya yang juga dilakukan di RSUP Prof. Dr. R. D. Kandou menunjukkan hasil yang sama, dimana dari semua jenis kasus tuberkulosis yang ada, kasus baru menempati peringkat pertama dengan jumlah pasien 38 orang $(86,4 \%){ }^{16}$

Tabel 4. Distribusi pasien TB paru menurut jenis kasus

\begin{tabular}{cccc}
\hline \multirow{2}{*}{ Jenis kasus } & $\begin{array}{c}\text { Rawat } \\
\text { Inap }\end{array}$ & $\begin{array}{c}\text { Rawat } \\
\text { Jalan }\end{array}$ & Total \\
\cline { 2 - 4 } Jumlah & Jumlah & Jumlah \\
\hline Baru & 1 & 12 & 13 \\
Gagal terapi & 0 & 1 & 1 \\
Putus Obat & 3 & 5 & 8 \\
Relaps & 2 & 6 & 8 \\
Total & 6 & 24 & 30 \\
\hline
\end{tabular}

Data yang diteliti di Puskesmas Bahu 
Malalayang I Manado pada tahun 2012 juga menunjukkan bahwa jumlah pasien pada kasus baru yang tertinggi, yaitu mencapai 53 pasien $(91,38 \%) .{ }^{17}$ Hal ini sebanding dengan jumlah pemakaian obat anti tuberkulosis, dimana pada penelitian ini ditemukan sekitar $75 \%$ dari sampel penelitian menggunakan OAT kategori 1. Pasien yang termasuk dalam pengobatan kategori 1 ialah pasien tuberculosis yang baru terkonfirmasi bakteriologis (BTA positif), berdasarkan gambaran klinis (BTA negatif namun foto toraks positif), dan tuberkulosis ekstra paru. ${ }^{16}$

Tabel 5. Distribusi pasien TB paru jenis OAT

\begin{tabular}{cccc}
\hline \multirow{2}{*}{ Jenis } & $\begin{array}{c}\text { Rawat } \\
\text { Inap }\end{array}$ & $\begin{array}{c}\text { Rawat } \\
\text { Jalan }\end{array}$ & Total \\
\cline { 2 - 4 } & Jumlah & Jumlah & Jumlah \\
\hline Kategori 1 & 4 & 20 & 24 \\
Kategori 2 & 2 & 4 & 6 \\
\hline
\end{tabular}

Pada penelitian didapatkan hasil pemeriksaan eritrosit urin menunjukkan hematuria terjadi paling banyak pada kelompok usia 56-65 tahun, yaitu pada 3 dari 4 orang pasien yang mengalami hematuria asimtomatik. Hal ini didukung oleh penelitian yang dilakukan oleh Bauer $^{7}$ yang menunjukkan bahwa sebanyak 13\% orang dewasa mengalami hematuria asimtomatik, dimana usia lebih dari 40 tahun memiliki risiko yang lebih tinggi untuk mengalami hematuria (Tabel 6).

Pada pemeriksaan, pasien laki-laki yang mengalami hematuria ialah 3 orang (15\%) dari 20 orang pasien laki-laki, sedangkan pasien perempuan yang mengalami hematuria ialah 1 orang (10\%) dari 10 orang pasien perempuan. Menurut Grossfeld et al. ${ }^{18}$ para laki-laki terutama pada usia yang lebih tua, berisiko terkena penyakit urologi dan memiliki prevalensi sekitar $21 \%$ untuk terkena hematuria (Tabel 7).

Berdasarkan karakteristik pengobatan tuberkulosis yang dijalani, hematuria paling banyak terjadi pada jenis kasus TB putus obat sebanyak 2 orang (50\%), dengan pengobatan kategori 1 sebanyak 3 orang (75\%), dan pada pasien yang sedang menjalani terapi sekitar 3-4 bulan sebanyak 2 orang $(50 \%)$.

Tabel 6. Distribusi hasil pemeriksaan eritrosit urin berdasarkan usia

\begin{tabular}{|c|c|c|c|c|c|c|c|}
\hline \multirow{3}{*}{ Usia } & \multicolumn{7}{|c|}{ Eritrosit Urin } \\
\hline & \multicolumn{5}{|c|}{ Kimia } & \multicolumn{2}{|c|}{$\begin{array}{c}\text { Mikroskopik } \\
\text { (sel/LPB) }\end{array}$} \\
\hline & $\mathrm{Neg}$ & Trace-intact & Trace-lysed & + & ++ & $0-2$ & $\geq 3$ \\
\hline 18-25 Tahun & 3 & 0 & 0 & 1 & 0 & 4 & 0 \\
\hline 26-35 Tahun & 1 & 1 & 0 & 1 & 1 & 3 & 1 \\
\hline 36-45 Tahun & 4 & 2 & 1 & 1 & 0 & 8 & 0 \\
\hline 46-55 Tahun & 1 & 1 & 1 & 3 & 0 & 6 & 0 \\
\hline 56-65 Tahun & 2 & 1 & 0 & 0 & 3 & 3 & 3 \\
\hline 66-75 Tahun & 0 & 2 & 0 & 0 & 0 & 2 & 0 \\
\hline Total & 11 & 7 & 2 & 6 & 4 & 26 & 4 \\
\hline
\end{tabular}

Tabel 7. Distribusi hasil pemeriksaan eritrosit urin berdasarkan jenis kelamin

\begin{tabular}{|c|c|c|c|c|c|c|c|}
\hline \multirow{3}{*}{$\begin{array}{c}\text { Jenis } \\
\text { Kelamin }\end{array}$} & \multicolumn{7}{|c|}{ Eritrosit Urin } \\
\hline & \multicolumn{5}{|c|}{ Kimia } & \multicolumn{2}{|c|}{$\begin{array}{c}\text { Mikroskopik } \\
\text { (sel/LPB) }\end{array}$} \\
\hline & $\mathrm{Neg}$ & Trace-intact & Trace-lysed & + & ++ & $0-2$ & $\geq 3$ \\
\hline Laki-laki & 7 & 5 & 2 & 3 & 3 & 17 & 3 \\
\hline Perempuan & 4 & 2 & 0 & 3 & 1 & 9 & 1 \\
\hline Total & 11 & 7 & 2 & 6 & 4 & 26 & 4 \\
\hline
\end{tabular}


Tabel 8. Distribusi hasil pemeriksaan eritrosit urin berdasarkan jenis kasus TB

\begin{tabular}{|c|c|c|c|c|c|c|c|}
\hline \multirow{3}{*}{$\begin{array}{c}\text { Jenis Kasus TB } \\
\text { Paru }\end{array}$} & \multicolumn{7}{|c|}{ Eritrosit Urin } \\
\hline & \multicolumn{5}{|c|}{ Kimia } & \multicolumn{2}{|c|}{$\begin{array}{c}\text { Mikroskopik } \\
\text { (sel/LPB) }\end{array}$} \\
\hline & Neg & Trace-intact & Trace-lysed & + & ++ & $0-2$ & $\geq 3$ \\
\hline Baru & 6 & 2 & 0 & 4 & 1 & 12 & 1 \\
\hline Putus obat & 2 & 2 & 1 & 1 & 2 & 6 & 2 \\
\hline Gagal terapi & 1 & 0 & 0 & 0 & 0 & 1 & 0 \\
\hline Relaps & 2 & 3 & 1 & 1 & 1 & 7 & 1 \\
\hline
\end{tabular}

Tabel 9. Distribusi hasil pemeriksaan eritrosit urin berdasarkan jenis pengobatan

\begin{tabular}{|c|c|c|c|c|c|c|c|}
\hline \multirow{3}{*}{$\begin{array}{c}\text { Jenis } \\
\text { Pengobatan TB } \\
\text { Paru }\end{array}$} & \multicolumn{7}{|c|}{ Eritrosit Urin } \\
\hline & \multicolumn{5}{|c|}{ Kimia } & \multicolumn{2}{|c|}{$\begin{array}{l}\text { Mikroskopil } \\
\text { (sel/LPB) }\end{array}$} \\
\hline & $\mathrm{Neg}$ & Trace-intact & Trace-lysed & + & ++ & $0-2$ & $\geq 3$ \\
\hline Kategori 1 & 10 & 5 & 1 & 5 & 3 & 21 & 3 \\
\hline Kategori 2 & 1 & 2 & 1 & 1 & 1 & 5 & 1 \\
\hline
\end{tabular}

Tabel 10. Distribusi hasil pemeriksaan eritrosit urin berdasarkan lama pengobatan

\begin{tabular}{|c|c|c|c|c|c|c|c|}
\hline \multirow{3}{*}{$\begin{array}{c}\text { Lama } \\
\text { Pengobatan }\end{array}$} & \multicolumn{7}{|c|}{ Eritrosit Urin } \\
\hline & \multicolumn{5}{|c|}{ Kimia } & \multicolumn{2}{|c|}{$\begin{array}{c}\text { Mikroskopik } \\
\text { (sel/LPB) }\end{array}$} \\
\hline & $\mathrm{Neg}$ & Trace-intact & Trace-lysed & + & ++ & $0-2$ & $\geq 3$ \\
\hline$<1$ bulan & 7 & 4 & 1 & 1 & 0 & 13 & 0 \\
\hline $1-2$ bulan & 2 & 2 & 0 & 2 & 1 & 6 & 1 \\
\hline 3-4 bulan & 0 & 0 & 1 & 1 & 2 & 2 & 2 \\
\hline 5- 6 bulan & 1 & 0 & 0 & 0 & 0 & 1 & 0 \\
\hline$>6$ bulan & 1 & 1 & 0 & 2 & 1 & 4 & 1 \\
\hline
\end{tabular}

Rifampisin menimbulkan efek nefrotoksik ketika obat tersebut digunakan secara intermiten dengan interval berkisar dari 5 bulan sampai 11 tahun yang akan bermanifestasi 10-20 hari saat pengobatan dimulai kembali. ${ }^{19}$ Pada beberapa kasus dilaporkan nefrotoksisitas terjadi setelah $>2$ bulan terapi, meskipun reaksi awal juga dapat muncul dalam 13 hari pengobatan. ${ }^{20}$ Sementara itu streptomisin yang merupakan golongan aminoglikosida bersifat nefrotoksik tergantung pada dosis dan durasi terapi, dimana nefrotoksik timbul pada pemberian dosis tinggi dan terapi jangka panjang. ${ }^{21}$ Resiko nefrotoksisitas meningkat pada lama pengobatan diatas 10 hari. $^{22}$ Berdasarkan teori tentang jenis pengobatan pada kasus putus obat diberikan OAT kategori 2 .
Namun pada penelitian ini didapatkan kejadian hematuria paling banyak pada pasien dengan pengobatan TB kategori 1, hal ini kemungkinan disebabkan karena populasi pasien kasus baru mendominasi dan kebanyakan pasien kasus relaps dan putus obat masih diberikan terapi OAT kategori 1.

Berdasarkan ada atau tidaknya penyakit penyerta, pemeriksaan eritrosit urin menunjukkan hasil hematuria paling banyak dialami oleh pasien dengan penyakit penyerta yaitu pada 3 orang dari 14 pasien $(21,4 \%)$. Menurut hasil anamnesis dan dari rekam medis pasien, ternyata 2 dari 3 orang tersebut memiliki penyakit ginjal dan 1 orang lagi menderita diabetes mellitus. 
Sinaga, Rambert, Wowor: Gambaran eritrosit urin...

Tabel 11. Distribusi hasil pemeriksaan eritrosit urin berdasarkan penyakit penyerta

\begin{tabular}{|c|c|c|c|c|c|c|c|}
\hline \multirow{3}{*}{$\begin{array}{l}\text { Penyakit } \\
\text { penyerta }\end{array}$} & \multicolumn{7}{|c|}{ Eritrosit Urin } \\
\hline & \multicolumn{5}{|c|}{ Kimia } & \multicolumn{2}{|c|}{$\begin{array}{c}\text { Mikroskopik } \\
\text { (sel/LPB) }\end{array}$} \\
\hline & $\mathrm{Neg}$ & Trace-intact & Trace-lysed & + & ++ & $0-2$ & $\geq 3$ \\
\hline Ada & 3 & 3 & 2 & 3 & 3 & 11 & 3 \\
\hline Tidak ada & 8 & 4 & 0 & 3 & 1 & 15 & 1 \\
\hline Total & 11 & 7 & 2 & 6 & 4 & 26 & 4 \\
\hline
\end{tabular}

Penyakit ginjal dapat dalam keadaan tertentu dan tergantung tingkat keparahannya dapat menurunkan laju filtrasi glomerulus. Diabetes mellitus dapat menimbulkan komplikasi pada ginjal berupa nefropati diabetik yang termasuk dalam komplikasi mikrovaskular, yaitu komplikasi yang terjadi pada pembuluh darah halus (kecil). Kerusakan pembuluh darah menimbulkan kerusakan glomerulus yang berfungsi sebagai penyaring darah. Tingginya kadar gula dalam darah akan membuat struktur ginjal berubah sehingga fungsinya pun terganggu. Ketika fungsi glomerulus telah rusak maka zat-zat yang berukuran >3-7 $\mathrm{nm}$ yang dapat melewati glomerulus, diantaranya protein dan sel-sel darah. ${ }^{11}$

Pada penelitian ini terdapat 1 orang pasien yang mengalami hematuria tanpa adanya penyakit penyerta merupakan pasien dengan kasus tuberkulosis putus obat yang sudah menjalani terapi OAT kategori 1 selama 4 bulan.

Pada penelitian ini ditemukan perbedaan antara hasil urinalisis secara kimia dengan pemeriksaan sedimen urin secara mikroskopik. Hasil trace pada pemeriksaan kimia urin masih dianggap sebagai hasil negatif. ${ }^{23}$ Pada pemeriksaan eritrosit urin secara kimia menggunakan metode carik-celup didapatkan hasil negatif pada 20 pasien dan hasil positif pada 10 pasien, sedangkan pemeriksaan eritrosit urin dengan menggunakan mikroskop ditemukan hasil normal pada 26 pasien dan hasil hematuria pada 4 pasien.

Hasil urinalisis menggunakan alat urine analyzer dan mikroskop pada umumnya menunjukkan hasil normal pada eritrosit urin sampel penelitian. Walaupun pada pemeriksaan kimia urin ada ditemukan hasil trace-intact, trace-lysed dan small, namun ternyata setelah dilakukan pemeriksaan mikroskopik sedimen urin ditemukan jumlah eritrosit yang masih dalam batas normal, yaitu 0-2 sel/LPB. Hal ini kemungkinan disebabkan oleh beberapa hal diantaranya keterbatasan reagen yang kurang mampu membedakan antara eritrosit dengan mioglobin atau hemoglobin. Selain itu, urin dengan $\mathrm{pH}$ basa atau dengan berat jenis yang sangat rendah dapat menyebabkan eritrosit lisis dan melepaskan hemoglobin dalam urin. Ketika hemoglobin lepas maka akan terlihat membran eritrosit yang kosong, yang sering disebut sebagai "ghost cells". ${ }^{24}$

Penjelasan tentang hubungan tuberkulosis paru dewasa dan pemeriksaan eritrosit urin masih kurang lazim dilaporkan atau diteliti. Pada penelitian ini juga tidak dapat dilakukan uji beda hasil eritrosit urin pada pasien rawat inap dan rawat jalan akibat jumlah sampel yang tidak seimbang.

\section{SIMPULAN}

Berdasarkan hasil penelitian yang dilakukan di RSUP Prof. Dr. R.D. Kandou Manado, maka dapat disimpulkan bahwa pada penyakit tuberkulosis paru lebih banyak ditemukan pada laki-laki dan pada kelompok usia 36-45 tahun. Penyakit penyerta terbanyak pada pasien tuberkulosis paru adalah diabetes mellitus dan gangguan ginjal. Hasil pemeriksaan eritrosit urin pada umumnya normal. Namun hematuria didapatkan lebih banyak pada pasien laki-laki, pada kelompok usia 
56-65 tahun, pada jenis kasus putus obat, pada jenis pengobatan kategori 1, pada lama pengobatan 3-4 bulan, dan pada pasien dengan penyakit penyerta.

\section{SARAN}

Jumlah sampel penelitian diperbanyak untuk menghindari terjadinya bias dalam penelitian. Perlu penerapan metode analitik sehingga bisa mengetahui adanya hubungan sebab akibat antara kedua variabel tuberkulosis paru dan eritrosit urin. Perlu infromasi lebih lengkap tentang data pasien atau subjek penelitian.

\section{DAFTAR PUSTAKA}

1. Kementerian Kesehatan RI, Direktorat Jenderal Pengendalian Penyakit dan Penyehatan Lingkungan. Pedoman Nasional Pengendalian Tuberkulosis. 2014.

2. World Health Organization. Global Tuberculosis Report 2016.

3. Kementerian Kesehatan RI, Badan Penelitian dan Pengembangan Kesehatan. Riset Kesehatan Dasar. 2013.

4. Kementerian Kesehatan RI. Pedoman Nasional Pelayanan Kedokteran: Tata Laksana Tuberkulosis. 2013.

5. Chang CH, Chen YF, Wu VC, Shu CC, Lee CH, Wang JY, et al. Acute kidney injury due to anti-tuberculosis drugs: a five year experience in an aging population. BioMed Central Infectious Disease. 2014;14:23-31.

6. Decloedt E, Maartens G. Drug-induced renal injury. CME. 2011;29(6):252-5.

7. Bauer, DC. Evaluation of hematuria in adults. West J Med. 1990;152:305-8.

8. Sherwood L. The Urinary System. In: Arbogast M, editor. Human Physiology: From Cells to System. $7^{\text {th }}$ ed. Canada: Brooks/Cole; 2010. p. 511-7.

9. Armstrong, JA. Urinalysis in western culture: A brief history. Kidney International. 2007;71:384-7.

10.Simerville JA, Maxted WC, Pahira JJ. Urinalysis: A Comprehensive Review. Am Fam Physician. 2005;71:1153-62.

11.McLafferty. The urinary system. Nursing Standard. 2014;28(27):43-50.
12.Mori T. Tuberculosis epidemiology in the Asia-Pacific region. Respirology. 2008;56-64.

13.Zhang $X$, Andersen AB, Lillebaek T, Kamper-Jorgensen $Z$, Thomsen VO, Ladefoged $\mathbf{K}$, et al. Effect of Sex, Age, and Race on the Clinical Presentation of Tuberculosis: A 15Year Population-Based Study. Am J Trop Med Hyg. 2001;85(2):285-90.

14.Annisa R, Fauzi ZA, Fridayenti. Perbedaan Kadar SGPT pada Pasien Tuberkulosis Paru Sebelum dan Sesudah Fase Intensif di Poliklinik Paru RSUD Arifin Achmad Pekanbaru. JOM FK. 2015;2(20):110.

15.Mimi N, Medregoniu D, Olteanu M, Golli A. Tuberculosis and Chronic Renal Failure; Therapy Patterns. Current Health Sciences Journal. 2011;37(2):106-8.

16.Simamora V, Tjitrosantoso, Wiyono WI. Evaluasi Penggunaan Obat Antituberkulosis pada Pasien Tuberkulosis Paru di Instalasi Rawat Inap BLU RSUP Prof. Dr. R.D. Kandou Manado Periode JanuariDesember 2010. [Skripsi]. Manado: Universitas Sam Ratulangi;2011.

17.Sihotang RH, Lampus B, Pandelaki AJ. Gambaran Penderita Tuberkulosis Paru yang Berobat Menggunakan DOTS di Puskesmas Bahu Malalayang I Periode JanuariDesember 2012. Jurnal Kedokteran Komunitas dan Tropik. 2013;1(1):6872.

18. Grossfeld G, Wole JS, Litwin MS, Hricak $\mathrm{H}$, Shuler C, Agerter D, et al. Asymptomatic Microscopic Hematuria in Adults: Summary of the AUA Best Practice Policy Recommendations. Am Fam Physician. 2001;63:1145-54.

19.Beebe A, Seaworth B, Patil N. Rifampisininduced Nephrotoxicity in A Tuberculosis Patient. Journal of Clinical Tuberculosis and Other Mycobacterial Diseases. 2015;1:13-5.

20.Singh NP, Ganguli A, Prakash A. DrugInduced Kidney Disease. JAPI. 2003;51:970-9.

21.Sandhu JS, Sehgal A, Gupta O, Singh A. Aminoglycoside Nephrotoxicity 
Revisited. JIACM. 2007;8(4):331-3.

22. Naughton

CA. Drug-Induced

Nephrotoxicity. Am Fam Physician. 2009;78(6):743-50.

23. BPAC Better Medicine. Interpreting urine dipstick tests in adults. BT 2013;10:10-21.
24.Mundt LA, Shanahan K. Chemical Analysis of Urine. In: Graff's Textbook of Routine Urinalysis and Body Fluids. $2^{\text {nd }}$ ed. Philadelphia: Lippincott Williams \& Wilkins; 2011. p. 43-5. 